\title{
The brand image and performance of small and medium enterprises: How can social responsibility activities help?
}

\author{
Authors: \\ Chantal Rootman ${ }^{1}$ \\ Bomikazi Zeka ${ }^{1}$ \\ Affiliations: \\ ${ }^{1}$ Department of Business \\ Management, Nelson \\ Mandela Metropolitan \\ University, South Africa \\ Correspondence to: \\ Chantal Rootman \\ Email: \\ chantal.rootman@nmmu. \\ ac.za \\ Postal address: \\ PO Box 77000, Port Elizabeth \\ 6031, South Africa \\ Dates: \\ Received: 28 Jan. 2013 \\ Accepted: 27 Mar. 2013 \\ Published: 25 Apr. 2013 \\ How to cite this article: \\ Rootman, C. \& Zeka, B., \\ 2013, 'The brand image and \\ performance of small and \\ medium enterprises: How \\ can social responsibility \\ activities help? ', Acta \\ Commercii 13(1), Art. \#171, \\ 9 pages. http://dx.doi. \\ org/10.4102/ac.v13i1.171

\section{Copyright:} \\ (C) 2013. The Authors. \\ Licensee: AOSIS \\ OpenJournals. This work \\ is licensed under the \\ Creative Commons \\ Attribution License.
}

Read online:
Orientation: Business social responsibility (BSR) activities may lead to benefits for small and medium enterprises (SMEs).

Research purpose: To investigate how SMEs could use BSR activities to improve their brand image and business performance.

Motivation for the study: In a competitive environment, SMEs face various challenges such as financial constraints, lack of resources or lack of managerial experience. BSR activities pave the way for an SME to make a positive contribution toward the environment in which it operates, as they indicate a level of care for the natural environment and show commitment toward the upliftment of communities. The benefits that accrue to SMEs that engage in BSR activities are yet to be determined and the need for research on SMEs' BSR activities and results led to this study.

Research design, approach and method: Structured questionnaires were distributed to 320 SMEs in the Eastern Cape, South Africa. A total of 200 usable questionnaires were received, obtaining a response rate of $62.5 \%$, and these were analysed quantitatively.

Main findings: Significant relationships were found between three BSR activities, namely stakeholder relations, community development and environmental awareness, and the SME's brand image; as well as between the SME's brand image and business performance.

Practical and managerial implications: Implemented BSR recommendations may lead to improved brand images and business performance; and therefore an increased success rate amongst SMEs in South Africa.

Contribution and value-add: BSR research has predominantly been in the sphere of larger and more established enterprises. The study suggests practical recommendations to SMEs to improve their brand image and business performance by employing BSR strategies relating to stakeholder relations, community development and environmental awareness.

\section{Introduction}

Social responsibility revolves around the concept of enterprises committing their resources to make positive and noticeable contributions for social causes. Business social responsibility (BSR) refers to the commitment to improve community wellbeing through discretionary business practices and the contributions of corporate resources (Kumar \& Tiwari 2011:22). Business activities might include actions that influence the welfare of society, such as assisting in the alleviation of social issues in communities. However, should BSR be seen as a business opportunity or an obligation?

The BSR initiative that exists in enterprises often occurs as a response to existing social issues, such as unemployment. For example, as a result of low employment rates, an enterprise might provide free food parcels regularly to its local community. There are various activities that may be considered as BSR activities and, more broadly, BSR entails the relationship between the enterprise, community/society and the natural environment in which an enterprise operates. BSR is important as it addresses the multiple needs of an enterprise's stakeholders (Werther Jr \& Chandler 2006:138).

Although there are various drivers for the implementation of BSR in different enterprises, in a globally-interconnected world an enterprise cannot ignore the need of engaging in BSR activities, regardless of the reason for so doing. The classical economic argument, which states that the primary purpose of any enterprise is to maximise the profits for its owners, still prevails amongst certain small and medium enterprise (SME) owners and/or managers. This school of thought, led by Milton Friedman, argues that any issues that occur in the social environment are not of concern to an enterprise. Even more so, it has been argued that enterprises are not humans and thus cannot have a moral or social responsibility for their actions. As enterprises are created 
by people, it is thus those individuals that should be held accountable for the enterprise's socially irresponsible deeds (Carroll \& Buchholtz 2006:41; Crane \& Matten 2007:44; Frederick 2002:304). It cannot be disputed that an enterprise should not ignore its primary economic reason for existence, yet it should also be kept in mind that enterprises operate in an encompassing ecology that is founded upon the principle of interdependence. An enterprise realises its profits through providing products and/or services to meet the needs of its consumers. These products that are manufactured and services that are rendered also form part of the ecology. In this way, the concept of ecological economics is introduced. Ecological economics is an economic perspective that addresses the interdependence and coevolution between human economies and their natural ecosystems (Xepapadeas 2008). Based on this principle, enterprises operate in societies and societies are part of the (social and natural) ecology. Without a healthily-functioning ecology, there can be no society, and without a society, there is no way in which an enterprise can achieve its goal of realising a profit. This notion further reiterates the importance of BSR, as social investment is a tool in which enterprises can sustain the natural environment in which they operate (Thorne, Ferrell \& Ferrell 2008:317). BSR is thus also important from a society's economic point of view, as it assists in alleviating various social issues that enterprises are partially responsible for creating (Frederick 2002:304). Following this discussion, BSR might be seen as an obligation.

However, the extent to which BSR can be a business opportunity is yet to be determined. For example, it is important to identify whether BSR can lead to an improved brand image or greater business performance for an enterprise implementing activities such as community development, environmental protection campaigns or ensuring diversity in the workplace.

There have been many studies that have discussed the BSR activities of larger, more established enterprises and the consequent outcomes thereof. However, research that has been conducted shows contradictory findings as to whether there is a positive relationship between BSR and business performance (Anderson \& Frankle 1980; Bampton, Odemilin \& Samy 2010:204; Belkaoui 1976; Cooke 2010:73; Orlitzky, Schmidt \& Rynes 2003:404). In addition, it is believed that SMEs are in a position to implement BSR with more ease and less administration, as a result of their organisational structure (Kongolo 2010:2290). There is also reason to believe that BSR might play a vital role in the success of enterprises, particularly that of SMEs. Therefore, the need for research on BSR in SMEs is evident.

Following this discussion, to answer the question in the introduction: 'Can BSR be seen as a business opportunity or an obligation?', it is important to perform research and investigate to which extent BSR can be an opportunity - where the implementation thereof leads to favourable outcomes of SMEs. Therefore, this study attempts to address the need for BSR research in SMEs by investigating the influence of BSR on the brand image and business performance of these enterprises.

\section{Purpose and objectives}

The primary objective of the study was to identify and investigate the influence of BSR activities on the brand image and business performance of SMEs. A hypothetical model in this regard was tested empirically.

In order to attain the primary objective, the following secondary objectives were pursued:

- to investigate literature on SMEs and relevant BSR activities

- to investigate literature on brand image and business performance

- to perform an empirical investigation among SMEs in the Eastern Cape

- to propose recommendations based on the empirical results to SMEs, on how to improve brand image and business performance by implementing appropriate BSR strategies.

\section{Literature review}

A literature review was conducted and the following sections contain a discussion on the concepts of BSR, brand image and business performance. The possible relationships between these three concepts in SMEs will be highlighted.

\section{The importance of business social responsibility}

BSR pertains to the actions of an enterprise that aims to achieve a social benefit over and above its intentions of maximising profits for its shareholders and meeting all its legal obligations (Ghillyer 2008:59). Therefore, BSR makes reference to an enterprise's responsibility to the society that goes beyond the production of products and/or services at a profit.

Crane and Matten (2007:48) states that enterprises cause social problems such as pollution or perhaps even unsafe work conditions. It is, therefore, the responsibility of the enterprise to eradicate those problems and prevent them from occurring in future. For this reason, enterprises should use their resources in a socially responsible manner. Enterprises have a social influence on the community, whether it is through the products and/or services that are provided, through the acquisition of employees, or through any other business activity. The enterprise is thus responsible for these influences, whether they are positive or negative, and should, consequently, act on these if and when necessary.

The implementation of an effective BSR strategy may fulfil the expectations of society, support the community in which an SME operates, generate profits and also create more value for shareholders (Birch 2005:73). It is important for an enterprise to be seen as part of the community, as a good 
reputation is necessary in a competitive environment (Cooke 2010:78). According to Crane and Matten (2007:47), some enterprises embark on BSR activities in order to be perceived as being socially responsible and this could attract more satisfied customers. A socially irresponsible enterprise may result in unfavourable customer actions such as defections. Positive contributions to the community can be beneficial to an enterprise in the long-term, as this may create a more stable business environment.

Furthermore, the benefits that accrue to enterprises in the adoption of BSR may be factors such as consumer loyalty, employee satisfaction and better stakeholder relations. Therefore, McWilliams, Siegel and Wright (2006:18) believe that the most important motive for BSR in SMEs is that the strategic use of philanthropy gives enterprises a competitive edge over those that do not make use of BSR.

According to Frederick (2002:304), enterprises should adapt their business strategies to incorporate BSR should they want to ensure their survival. Jenkins (2009:21) emphasises that integrating BSR into the core of an enterprise is crucial to its success. Werther Jr and Chandler (2006:138) confirm that enterprises that are most likely to succeed in the 21st century's evolving environment are those that balance the interests of their multiple stakeholders through BSR. In doing so, an enterprise also creates a better environment for itself through assisting in solving social problems. In this way, enterprises can gain a positive public image and also create business opportunities through working with the community in solving societal concerns.

\section{Business social responsibility activities relevant to small and medium enterprises}

There are various activities of BSR that have been identified in literature. However, for the purposes of this study, diversity, environmental awareness, community development and stakeholder relations are the activities that will be used to investigate the influence of BSR on the brand image of SMEs, as these are the most commonly-recognised BSR activities in SMEs.

An enterprise can act in a socially responsible manner by focusing on its diversity. Diversity refers to the presence of different cultures, languages, ethnicities, races, genders, religions, ages and nationalities in the enterprise (Hartman \& DesJardins 2011:281). Furthermore, diversity is seen as being the recruitment and the retention of a diverse workforce, with diversity programmes that have the ethical obligation to employ and empower individuals regardless of age, gender, ethnicity, physical or mental ability (Thorne et al. 2008:240).

According to Thorne et al. (2008:317), environmental awareness refers to the incorporation of environmental issues in business strategies, for the maintenance of the quality of the natural environment. Furthermore, BSR toward the environment encompasses energy and waste management, as well as conservation and the sustainable management of natural resources. Bosch, Tait and Venter (2011:714) state that environmentalism refers to the organised efforts of an enterprise to protect and conserve the natural environment in which it operates.

SMEs can also be socially responsible through community development. Community development within the context of BSR refers to an enterprise's engagement in community activities with the aim of improving the quality and substance of the community members' lives and livelihoods (Visser et al. 2010:76). Carroll and Buchholtz (2006:472) believe that other than complying with the law, being ethical and maximising profits, an enterprise can have a positive influence on the community through donating the time and services of its employees or making financial contributions toward the development of the community. Through community development, enterprises can enhance the quality of the lives of the members of the community.

Another dimension of BSR is stakeholder relations. The term 'stakeholder relations' refers to the extent to which enterprise managers are willing to listen and respond to all stakeholders' needs and objectives (Werther Jr \& Chandler 2006:138). Thorne et al. (2008:68) elaborate that stakeholder relations is the degree to which an enterprise understands and addresses the needs of stakeholders. The implementation of an effective stakeholder relations policy can thus be regarded as BSR and can be considered to be part of a comprehensive approach to BSR.

This study proposes that these selected BSR activities might influence an SME's brand image.

\section{Brand image of small and medium enterprises}

Swystun (2007:60) asserts that brand image refers to the overall impression and unique associations that an enterprise communicates to its stakeholders and the public. Furthermore, brand image can be defined as the sum of all the perceptions, notions and associations about a product and/or service that is being formed in the consumers' minds (Vukasovic 2009:166).

In order to create a positive brand image, an association to the enterprise that is unique, strong and favourable is necessary. According to Keller (2008:56), the associations that consumers have are strengthened through personal relevance of the consumer and through consistency in promoting the brand image. An enterprise can thus establish a positive brand image through making their products and/or services relevant to the needs of their consumers. The uniqueness of the brand image creates a competitive advantage for the enterprise and provides the consumer with a reason to purchase the products, or make use of the services of the enterprise (Keller 2008:637).

BSR, through activities such as diversity, environmental awareness, community development and stakeholder relations, can provide an enterprise with various advantages, amongst which is (possibly) a positive brand image. 
A result of having a diverse workforce is that the brand image of the enterprise can be maintained and supported (Baumgarth \& Schmidt 2010:1252; Brønn \& Vrioni 2001:210). Furthermore, a good reputation or a positive image can be derived from an enterprise's environmental behaviour or environmental awareness (Chen 2010:309; Claver et al. 2007:614). The benefits that accrue to enterprises for being active in the development of the community are vast, and increased recognition and a positive brand image can occur (Carroll \& Buchholtz 2006:42; Javalgi et al. 2012:48). Finally, an SME's engagement in relations with its stakeholders may lead to the development of a positive brand image (Uddin, Hassan \& Tarique 2008:206; Weber 2008:259).

It is also known that South African SMEs that are establishing their brand images in consumers' minds through the promotion of BSR initiatives have attained positive business performance at different levels (Irwin 2003:306). Brand image is thus an important element in the success of an enterprise. A positive brand image can have strategic value for an enterprise, as it can enhance the competitiveness of the enterprise and generate growth and profitability (Banerjee 2008:59; Belén del Río, Vázquez \& Iglesias 2001:413; Juntunen et al. 2010:117). Therefore, a positive brand image might lead to improved business performance.

\section{Business performance of small and medium enterprises}

The success or level of business performance of an enterprise can be measured by the enterprise's growth in terms of sales turnover, profits, rates of return on investments, expansion, productivity, as well as decreases in costs and its employment turnover rate (Alasadi \& Abdelrahim 2007:7; Dockel \& Ligthelm 2005; Griffin, 2008; Jacobs 2011; Lasher, 2008; Thorne et al. 2008:28). There are many different indicators used to measure the performance of an enterprise. For the purposes of this study, business performance will constitute an increase in sales, a decrease in operating costs, an increase in productivity, a low employee turnover rate, a growth in employees, as well as an increase in return on total assets and profitability.

Santos (2011:491) asserts that BSR, at the level of SMEs, is associated with financial viability, as well as economic performance. According to Bampton et al. (2010:205), enterprises supporting the notion of a socially responsible business entity believe that the enterprise would be able to improve its business performance as a result of BSR. Birch (2005:73) upholds the belief that an enterprise may be able to fulfil the expectations of society, that it will support the community in which it operates, generate profits and also create shareholder value, should it implement a BSR strategy effectively.

\section{Research method and design}

The study being reported here attempted to identify the influence of four BSR activities (independent variables) on the brand image (intervening variable) and ultimately the business performance (dependent variable) of SMEs. The study followed the quantitative research design and tested empirically the set hypotheses (Zikmund et al. 2010:94).

Both primary and secondary sources were used to collect information on SMEs, BSR, brand image and business performance. Secondary sources included books, articles from journals and websites, whilst primary research was conducted by means of an empirical study. As no sample frame exists of all the SMEs in the Eastern Cape, the researchers used a non-probability sampling technique.

A self-developed and self-administered measuring instrument in the form of a structured questionnaire was distributed to a convenience sample of 320 SME owners and/or managers in the Eastern Cape. The language of communication was English and the questionnaire consisted of three sections. Section A gathered the biographical and demographic data of the SME owners and/or managers, including their gender, age and employment status. Section $\mathrm{B}$ of the questionnaire consisted of statements based on the literature review with regard to the four BSR activities (diversity, environmental awareness, community development and stakeholder relations). Finally, Section C consisted of statements, also based on the literature review, with regard to the brand image and business performance of SMEs. Sections B and $C$ made use of a five-point Likert-type scale ranging from 'strongly disagree' (1) to 'strongly agree' (5). The validity of the measuring instrument was ensured as experts in the field of entrepreneurship (including SME management) assisted with the questionnaire design.

Of the sample of 320 SMEs, the data from 200 usable questionnaires (representing a response rate of $62.5 \%$ ) were statistically analysed using the computer programmes Microsoft Excel, Statistica (Version 10.0) (2010) and SPSS (Version 20.0) (2011). Data analysis was performed in four phases:

- The study calculated descriptive statistics in order to summarise the information about the sample (Zikmund 2003:402).

- Exploratory Factor Analyses (EFA) were conducted to determine the validity of the data and Cronbach's alpha correlation coefficients were computed to test the reliability of the measuring instrument. Items with factor loadings of at least 0.4 are considered as valid (Hair et al. 1998:111). It is stated that Cronbach's alpha coefficients range from 0 to 1 , and that a test should have a Cronbach's alpha correlation coefficient greater than 0.70 (Hair et al. 2003:172). The reliability of a questionnaire or test depends on by how much the Cronbach's alpha correlation coefficient exceeds the 0.70 benchmark.

- The Pearson's Product Moment Correlations were calculated to determine the correlations between the study's variables. According to Hair et al. (2003:283), the Pearson correlation coefficient measures the association between two variables and the measurement ranges from -1.00 to +1.00 , with zero indicating no association between the two variables. Therefore, the Pearson 
correlation coefficients enabled the researchers to calculate and understand the strength and direction of relationships between the four independent variables (the BSR activities), the intervening variable (brand image) and the dependent variable (business performance).

- Finally, multiple regression analyses were used to test the influence of the four BSR activities, namely diversity, environmental awareness, community development and stakeholder relations, on the brand image of SMEs and, ultimately, on the business performance of SMEs. The regression analyses made it possible for the researchers to measure the mathematical variance of the relationships between the variables and to test the hypotheses formulated (Zikmund et al. 2010:592).

\section{Hypotheses}

As the purpose of this study is to investigate the influence of BSR on the brand image and business performance of SMEs, a hypothetical model was constructed (see Figure 1).

As shown in Figure 1, the following hypotheses were constructed in order to determine whether relationships exist between each of the four BSR activities (diversity, environmental awareness, community development and stakeholder relations) and brand image (intervening variable); and between brand image and the business performance (dependent variable) of SMEs:

$\mathrm{H}^{1}$ : There is a significant positive relationship between diversity and brand image.

$\mathrm{H}^{2}$ : There is a significant positive relationship between environmental awareness and brand image.

$\mathrm{H}^{3}$ : There is a significant positive relationship between community development and brand image.

$\mathrm{H}^{4}$ : There is a significant positive relationship between stakeholder relations and brand image.

$\mathrm{H}^{5}$ : There is a significant positive relationship between brand image and business performance.

\section{Results: Empirical findings}

This section will elaborate on the empirical findings obtained from the statistical data analyses described above. The empirical results are categorised under a number of headings. Firstly, the biographical data of the respondents are described. Secondly, the validity and reliability of the measuring instrument are evaluated through the presentation of the EFA results and Cronbach's alpha coefficients. Thereafter, the descriptive statistics on the variables are provided. Finally, the Pearson's correlation coefficients and multiple regression results are highlighted, illustrating the relationships between the independent, intervening and dependent variables.

\section{Sample description}

The SMEs that participated in the study employed fewer than 200 employees and most SMEs operated as service providers $(45.5 \%)$. The majority of the respondents indicated that they were white $(58.0 \%)$ and male $(58.5 \%)$. Furthermore, most respondents were between the ages of 30 and $49(51.0 \%)$ and held the position of manager in the SME (46.5\%).

\section{Trustworthiness of results}

\section{Validity}

The results of the EFA on the independent variables, diversity, environmental awareness, community development and stakeholder relations is presented in Table 1.

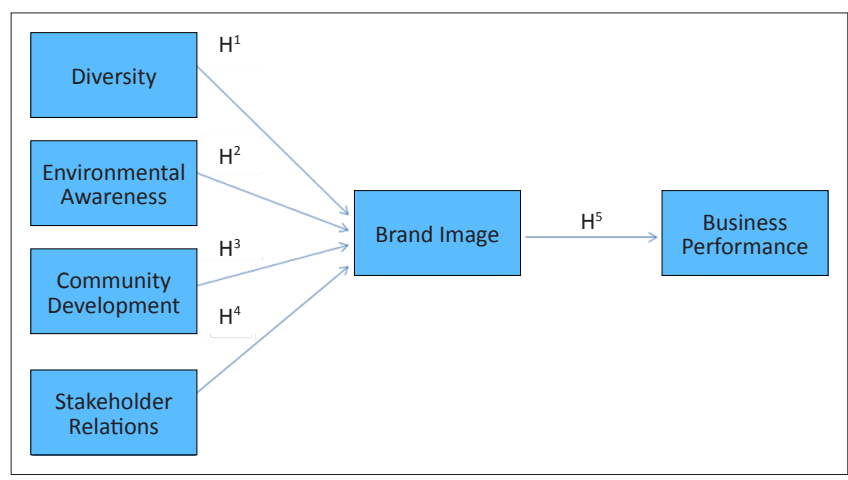

Source: Authors' own construction

FIGURE 1: Hypothetical model.

TABLE 1: Factor structure - independent variables.

\begin{tabular}{|c|c|c|c|c|}
\hline Items & $\begin{array}{l}\text { Stakeholder } \\
\text { relations }\end{array}$ & $\begin{array}{l}\text { Environmental } \\
\text { awareness }\end{array}$ & $\begin{array}{c}\text { Community } \\
\text { development }\end{array}$ & Diversity \\
\hline STAKE1 & 0.872 & 0.121 & 0.037 & 0.051 \\
\hline STAKE2 & 0.843 & 0.139 & 0.011 & 0.017 \\
\hline STAKE7 & 0.569 & 0.075 & 0.132 & 0.171 \\
\hline STAKE10 & 0.839 & 0.117 & 0.053 & 0.080 \\
\hline STAKE11 & 0.836 & 0.056 & 0.070 & 0.229 \\
\hline STAKE12 & 0.793 & 0.049 & 0.065 & 0.167 \\
\hline STAKE13 & 0.790 & 0.081 & 0.085 & 0.129 \\
\hline STAKE3 & 0.804 & 0.103 & 0.055 & -0.037 \\
\hline AWARE1 & 0.209 & 0.549 & 0.171 & 0.015 \\
\hline AWARE2 & 0.145 & 0.648 & 0.156 & 0.046 \\
\hline AWARE4 & 0.079 & 0.804 & 0.045 & 0.036 \\
\hline AWARE5 & 0.018 & 0.726 & 0.094 & 0.061 \\
\hline AWARE6 & 0.054 & 0.704 & 0.060 & -0.014 \\
\hline AWARE7 & 0.040 & 0.523 & 0.066 & 0.011 \\
\hline AWARE8 & 0.079 & 0.573 & 0.182 & 0.196 \\
\hline AWARE9 & 0.064 & 0.561 & 0.086 & 0.128 \\
\hline COMM2 & 0.068 & 0.163 & 0.596 & 0.037 \\
\hline COMM3 & 0.117 & 0.137 & 0.776 & 0.118 \\
\hline COMM4 & -0.047 & 0.290 & 0.542 & 0.068 \\
\hline COMM5 & 0.046 & 0.013 & 0.723 & -0.007 \\
\hline COMM6 & 0.148 & 0.123 & 0.687 & -0.080 \\
\hline COMM7 & 0.067 & -0.008 & 0.583 & 0.159 \\
\hline COMM8 & 0.014 & 0.182 & 0.537 & 0.150 \\
\hline DIV3 & 0.089 & 0.028 & 0.052 & 0.745 \\
\hline DIV4 & 0.165 & 0.044 & 0.017 & 0.710 \\
\hline DIV5 & 0.087 & 0.020 & 0.103 & 0.430 \\
\hline DIV6 & 0.121 & 0.075 & 0.105 & 0.626 \\
\hline DIV7 & -0.023 & 0.047 & 0.131 & 0.421 \\
\hline DIV9 & 0.077 & 0.092 & -0.077 & 0.412 \\
\hline $\begin{array}{l}\text { Explained } \\
\text { Variance }\end{array}$ & 5.295 & 3.580 & 3.076 & 2.257 \\
\hline $\begin{array}{l}\text { Proportion of } \\
\text { Total Variance }\end{array}$ & 0.183 & 0.123 & 0.106 & 0.078 \\
\hline
\end{tabular}

Source: Authors' own construction 
From Table 1 it can be seen that all the items displayed sufficient evidence of validity, as factor loadings of greater than 0.40 provide such evidence (Hair et al. 1998:111).

To measure the factor stakeholder relations, 13 items were developed initially, and eight items loaded. Factor loadings between 0.569 and 0.872 were reported for this factor, providing evidence of validity for this construct. Stakeholder relations explains $5.30 \%$ of the variance in the data. There had originally been 10 items that were developed to measure environmental awareness, and of those items, eight loaded onto the factor as expected. Factor loadings of between 0.523 and 0.804 were returned for environmental awareness, confirming the validity for this construct. Environmental awareness explains $3.58 \%$ of the variance in the data. The original 10 items that were formulated to measure the construct community development did not all load significantly. As seen in Table 1, seven of these items loaded together significantly. Factor loadings of between 0.537 and 0.776 were returned for community development which explains $3.08 \%$ of the variance in the data. Sufficient evidence of validity for this factor is thus provided. Of the 10 items that were intended to measure the factor diversity, six loaded together. Table 1 shows that factor loadings of between 0.412 and 0.745 were reported for this construct, thus evidence of validity for this factor is provided. In addition, diversity explains $2.26 \%$ of the variance in the data.

Table 2 presents the results of the EFA conducted for the intervening variable (brand image) and the dependent variable (business performance).

All nine items that were intended initially to measure the factor brand image loaded together onto one construct. Factor loadings of between 0.476 and 0.788 were reported for this factor. Sufficient evidence of validity is thus provided for this construct. The nine items measuring brand image explain $3.69 \%$ of the variance in the data. Finally, Table 2 shows that eight items were used originally to measure the construct business performance, of which six items loaded onto this construct as expected. Business performance reported factor loadings of between 0.503 and 0.785 , which provides evidence of validity for this construct. Business performance also explains $3.17 \%$ of the variance in the data. Based on the EFAs, items that did not load significantly were eliminated from further analysis.

\section{Reliability}

Table 3 presents the Cronbach's alpha coefficient for all the variables.

Consequently, a reliability estimate of between 0.60 and 0.70 is considered to be acceptable (Hair et al. 2006:778). It is evident that all variables or constructs met the requirements for reliability. The highest Cronbach's alpha coefficient of 0.923 was reported for stakeholder relations, which shows that the measuring scale for this construct can be regarded as being the most reliable.

\section{Descriptive statistics and relationships between variables}

The descriptive statistics of the variables were calculated and are shown in Table 4.

Stakeholder relations returned the highest mean score of 4.014, with most of the respondents agreeing that their SMEs have strong and positive relations with their stakeholders. However, community development reported the lowest mean score of 3.432, showing that the respondents were neutral regarding the fact that their enterprises' engage in activities that uplift local communities.

TABLE 2: Factor structure - intervening and dependent variables.

\begin{tabular}{lcc}
\hline Items & Brand image & Business performance \\
\hline BRAND1 & $\mathbf{0 . 5 4 7}$ & 0.177 \\
BRAND2 & $\mathbf{0 . 5 3 8}$ & 0.134 \\
BRAND3 & $\mathbf{0 . 6 4 4}$ & 0.226 \\
BRAND4 & $\mathbf{0 . 6 1 0}$ & 0.022 \\
BRAND5 & $\mathbf{0 . 6 8 7}$ & 0.114 \\
BRAND6 & $\mathbf{0 . 5 8 4}$ & 0.255 \\
BRAND7 & $\mathbf{0 . 7 8 8}$ & 0.216 \\
BRAND8 & $\mathbf{0 . 6 9 1}$ & 0.081 \\
BRAND9 & $\mathbf{0 . 4 7 6}$ & 0.139 \\
BUSPERF1 & 0.165 & $\mathbf{0 . 7 1 3}$ \\
BUSPERF3 & 0.228 & $\mathbf{0 . 6 4 4}$ \\
BUSPERF5 & 0.125 & $\mathbf{0 . 5 0 3}$ \\
BUSPERF6 & 0.099 & $\mathbf{0 . 7 8 5}$ \\
BUSPERF7 & 0.089 & $\mathbf{0 . 7 5 8}$ \\
BUSPERF8 & 0.262 & $\mathbf{0 . 7 4 5}$ \\
\hline Explained Variance & $\mathbf{3 . 6 9 2}$ & $\mathbf{3 . 1 7 4}$ \\
Proportion of Total Variance & $\mathbf{0 . 2 4 6}$ & $\mathbf{0 . 2 1 2}$ \\
\hline
\end{tabular}

Source: Authors' own construction

TABLE 3: Cronbach's alpha coefficients

\begin{tabular}{lc}
\hline Factors & Cronbach's alpha coefficient \\
\hline Independent variables & \\
Stakeholder relations & 0.923 \\
Environmental awareness & 0.852 \\
Community development & 0.835 \\
Diversity & 0.738 \\
Intervening variable & \\
Brand image & 0.846 \\
Dependent variable & \\
Business performance & 0.845 \\
\hline
\end{tabular}

Source: Authors' own construction

TABLE 4: Descriptive statistics on variables $(n=200)$

\begin{tabular}{lccccc}
\hline Factors & Mean & SD & $\begin{array}{c}\text { Disagree } \\
(\mathbf{\%})\end{array}$ & $\begin{array}{c}\text { Neutral } \\
(\mathbf{\%})\end{array}$ & $\begin{array}{c}\text { Agree } \\
\mathbf{( \% )}\end{array}$ \\
\hline $\begin{array}{l}\text { Independent variables } \\
\text { Diversity }\end{array}$ & 3.538 & 0.848 & 8.000 & 39.500 & 52.500 \\
Environmental awareness & 3.829 & 0.747 & 3.500 & 32.000 & 64.500 \\
Community development & 3.432 & 0.852 & 11.000 & 46.500 & 42.500 \\
Stakeholder relations & 4.014 & 0.824 & 4.500 & 21.000 & 74.500 \\
$\begin{array}{l}\text { Intervening variable } \\
\text { Brand image }\end{array}$ & 4.084 & 0.712 & 1.500 & 21.500 & 77.000 \\
$\begin{array}{l}\text { Dependent variable } \\
\text { Business performance }\end{array}$ & 3.928 & 0.744 & 4.000 & 23.000 & 73.000 \\
\hline $\begin{array}{l}\text { Source: Authors' own construction } \\
\text { SD, standard deviation. }\end{array}$ & & & & &
\end{tabular}

SD, standard deviation. 
TABLE 5: Pearson's correlations coefficients.

\begin{tabular}{|c|c|c|c|c|c|c|}
\hline \multirow[t]{2}{*}{ Factors } & \multicolumn{6}{|c|}{ Numbers (1-6) } \\
\hline & Diversity & $\begin{array}{c}\text { Environmental } \\
\text { awareness }\end{array}$ & $\begin{array}{c}\text { Community } \\
\text { development }\end{array}$ & $\begin{array}{c}\text { Stakeholder } \\
\text { relations }\end{array}$ & $\begin{array}{l}\text { Brand } \\
\text { image }\end{array}$ & $\begin{array}{c}\text { Business } \\
\text { performance }\end{array}$ \\
\hline 1. Diversity & 1.000 & 0.166 & 0.171 & 0.241 & 0.165 & 0.140 \\
\hline 3. Community development & 0.171 & 0.307 & 1.000 & 0.179 & 0.302 & 0.204 \\
\hline 4. Stakeholder relations & 0.241 & 0.234 & 0.179 & 1.000 & 0.438 & 0.276 \\
\hline 5. Brand image & 0.165 & 0.310 & 0.302 & 0.438 & 1.000 & 0.373 \\
\hline
\end{tabular}

Source: Authors' own construction

Pearson's coefficients range between -1 and 1. All coefficients are positive showing that the variables increase and decrease together. Values closer to 1 show stronger correlations.

Brand image returned a mean score of 4.084, with the majority of the respondents agreeing that their enterprises create unique associations that are communicated to stakeholders and the public at large. Finally, business performance returned a mean score of 3.928, with the majority of the respondents agreeing that their enterprises have experienced growth in terms of sales turnover, profits, rates of return on investments, expansion and productivity.

Table 5 reveals the results of the Pearson's Product Moment Correlations.

The Pearson's Product Moment Correlations show significant positive correlations between all the variables used in the study (ranging between 0 and 1 ). It is evident that there are positive correlations between the independent variables, the intervening variable and the dependent variable. That is to say, if one of these variables increases (improves) in a $\mathrm{SME}$, there will be a positive influence or increasing effect on another variable.

To support the Pearson's Product Moment Correlations results, in order to assess the influence of the various independent variables on the brand image (intervening variable) and business performance (dependent variable) of SMEs, multiple linear regression analyses were undertaken. Two separate regression models were undertaken for this purpose.

Table 6 portrays the first multiple linear regression analysis which considered the influence of the BSR activities (independent variables) on the brand image (intervening variable) of SMEs.

From the multiple linear regression analysis, a significant positive relationship $(0.000 ; p<0.001)$ is reported between stakeholder relations and brand image. Furthermore, significant positive relationships are also present between community development and brand image $(0.006 ; p<0.01)$ as well as between environmental awareness and brand image (0.013; $p<0.05)$. However, this study found a positive but not significant relationship between diversity and brand image. Therefore, the results show that SMEs that engage in environmental awareness, community development and stakeholder relations are likely to experience improved brand images, whereas diversity, as a dimension of BSR, has no significant influence on the brand image of an enterprise.
TABLE 6: Influence of the independent variables on the intervening variable

\begin{tabular}{lccc}
\hline Independent variables & \multicolumn{3}{c}{$\boldsymbol{R}$-Square $=\mathbf{0 . 2 6 8}$} \\
\cline { 2 - 4 } & Beta & $\boldsymbol{t}$-value & Sig. $(\boldsymbol{p})$ \\
\hline Diversity & 0.016 & 0.301 & 0.763 \\
Environmental awareness & 0.158 & 2.513 & $0.013^{*}$ \\
Community development & 0.153 & 2.807 & $0.006^{* *}$ \\
Stakeholder relations & 0.312 & 5.588 & $0.000^{* * *}$ \\
\hline
\end{tabular}

Stakeholder relations

${ }^{*}, p<0.05 ;{ }^{* *}, p<0.01 ;{ }^{* * *}, p<0.001$

TABLE 7: Influence of the independent variables and intervening variable on the dependent variable.

\begin{tabular}{lccc}
\hline $\begin{array}{l}\text { Independent and intervening } \\
\text { variables }\end{array}$ & \multicolumn{3}{c}{$\boldsymbol{R}$-Square $=\mathbf{0 . 1 7 1}$} \\
\cline { 2 - 4 } & $\mathbf{B e t a}$ & $\boldsymbol{t}$-value & $\mathbf{S i g} \cdot(\boldsymbol{p})$ \\
\hline Diversity & 0.037 & 0.613 & 0.541 \\
Environmental awareness & 0.083 & 1.174 & 0.242 \\
Community development & 0.061 & 0.977 & 0.330 \\
Stakeholder relations & 0.105 & 1.559 & 0.121 \\
Brand image & 0.281 & 3.516 & $0.001^{*}$ \\
\hline
\end{tabular}

Source: Authors' own construction

$*, p<0.01$

Table 7 shows the results of the multiple linear regression analysis conducted to determine the relationships between the independent and intervening variables (simultaneously) on the dependent variable (the business performance of SMEs).

Table 7 depicts the significant positive relationship that exists between brand image and business performance $(0.001 ; p<0.01)$. That is to say, an SME with a positive brand image is likely to increase its business performance.

As a result of the multiple linear regression analyses hypothesis $\mathrm{H}^{1}$ is rejected, as there is no significant relationship between diversity and the brand image of a SME. However, hypotheses $\mathrm{H}^{2}, \mathrm{H}^{3}, \mathrm{H}^{4}$ and $\mathrm{H}^{5}$ are accepted, as significant positive relationships exist between the BSR activities stakeholder relations, community development and environmental awareness, and the brand image of a SME. An SME's brand image also has a significant positive relationship with the SME's business performance.

\section{Ethical considerations}

Data collection aimed at identifying the extent to which SMEs engage in BSR activities, and as mentioned, a structured questionnaire was distributed to SME owners and/or managers for this purpose. The data collected was not of a private or personal nature, however, according to 
institutional guidelines a pro forma ethics clearance form was completed and submitted to, and acknowledged by, the Nelson Mandela Metropolitan University Business and Economic Sciences' Faculty RTI. Respondents were invited to participate and the completion of a questionnaire was considered as providing consent. However, participation was voluntary and respondents could withdraw at any stage. No personal credentials or identifiable data of respondents and their enterprises were collected, and data was treated with confidentiality. Collected data are stored on the authors' password protected computers and completed questionnaires are stored in a locked cabinet.

\section{Discussion: Managerial implications}

The primary objective of this study was to investigate the influence of BSR on the brand image and business performance of SMEs. The EFAs and the Cronbach's alpha coefficients confirmed evidence of validity and reliability for the measuring instrument used in this study.

The statistics calculated to analyse relationships between the variables revealed significant positive relationships between the BSR activities of stakeholder relations, community development and environmental awareness, and the brand image of SMEs. These results showed that SMEs that engage in positive relations with their stakeholders, are involved in community development projects, and incorporate environmental concerns into their business practices are likely to experience improved brand images. This concurs with Claver et al. (2007:614), Javalgi et al. (2012:48) and Uddin et al. (2008:206), who state that engaging in stakeholder relations, community development and environmental awareness leads to a positive brand image. However, diversity as a BSR activity in SMEs has a positive, but not significant influence on the brand image of an enterprise.

Considering the above findings, the researchers recommended the following practical actions for SMEs:

- Establish a BSR committee with individuals from various stakeholder groups to ensure equal representation as well as a unified vision.

- Encourage customers to bring forward any complaints, such as unsatisfactory purchased products and/or services.

- Implement health and safety programmes that assist the community in overcoming issues, such as drug or alcohol abuse.

- Provide internships for graduates or sponsor study and/ or research grants for students in local communities.

- Encourage employees to reduce their energy consumption levels by switching off electrical appliances when they are not in use.

- Encourage employees to participate in initiatives with regard to reducing the amount of waste produced.

Furthermore, the multiple linear regression analysis revealed that brand image exerts a significant positive influence on the business performance of an SME. This result corresponds with the researchers that advocate that a positive brand image does in fact lead to increased business performance (Banerjee 2008:59; Juntunen et al. 2010:117).

This relationship between the intervening and dependent variables led to the following recommendations for SMEs:

- Develop external campaign programmes to raise awareness of social or sustainable development issues, for example the need to reduce water consumption in times of water scarcity.

- Engage in marketing strategies that will promote brand names, for example, be associated with other highly regarded enterprises.

\section{Future research and final conclusion}

Some limitations were encountered during this study. The convenience sampling method proved to be a limitation, as this method has disadvantages such as being less representative of the population, providing a limited generalisation of the results as well as potential sampling bias (Cohen, Manion \& Morrison 2007:114; Springer 2010:107; Zikmund 2003:382). Future research should attempt to determine a database from which probability samples of SMEs can be drawn. Another limitation of this study is that it is focused on four BSR activities only. Other BSR activities, for example sponsorships, donations, product liability or consumerism, may exist and also influence the brand image and business performance of SMEs.

Although some limitations were encountered, this study adds to the field of BSR research in the sphere of SMEs, as a deeper understanding has been gained into the extent to which BSR influences the brand image and business performance of SMEs. Implemented recommendations made in this study may lead to an increased survival rate among SMEs. In addition, implemented BSR activities and outcomes will benefit communities.

\section{Acknowledgments Competing interests}

The authors declare that they have no financial or personal relationship(s) which may have inappropriately influenced them in writing this article.

\section{Authors' contributions}

C.R. and B.Z. (both Nelson Mandela Metropolitan University) contributed equally to this study and manuscript. Both authors were involved in the planning of the study and the literature review, as well as the empirical investigation and final write up.

\section{References}

Alasadi, R. \& Abdelrahim, A., 2007, 'Critical analysis and modelling of small business performance (Case Study: Syria)', Journal of Asia Entrepreneurship and Sustainability 3(2), 1-131.

Anderson, J. \& Frankle, A., 1980, 'Voluntary social reporting: an iso-beta portfolio analysis', Accounting Review 55(3), 468-479. 
Bampton, R, Odemilin, G. \& Samy, M., 2010, 'Corporate social responsibility: a strategy for sustainable business success. An analysis of 20 selected a strategy for sustainable business success. An analysis of 20 selected
British Companies', Corporate Governance 10(2), 203-207. http://dx.doi. British Companies', Corporate
org/10.1108/14720701011035710

Banerjee, S., 2008, 'Logo change: Little image touch up or serious overhaul! Imperatives and scanning parameters', Journal of Marketing \& Communication $4(1), 59-70$.

Baumgarth, C. \& Schmidt, M., 2010, 'How strong is the business-to-business brand in the workforce? An empirically-tested model of "internal brand equity" in business-to business setting', Industrial Marketing Management 39(8), 12501260. http://dx.doi.org/10.1016/j.indmarman.2010.02.022

Belén del Río, A., Vázquez, R. \& Iglesias, V., 2001, 'The effects of brand associations on consumer response', Journal of Consumer Marketing 18(5), 410-425. http:// dx.doi.org/10.1108/07363760110398808

Belkaoui, A., 1976, 'The impact of the disclosure of the environmental effects of organisational behaviour on the market', Financial Management 5(4), 6-31. http://dx.doi.org/10.2307/3665454

Birch, D., 2005, 'Sustainable development makes good business sense', paper presented at Australian Greenhouse Office and UITP, Brisbane, Australia, Octobe 27-28.

Bosch, J., Tait, M. \& Venter, E. (eds.), 2011, Business Management: An Entrepreneurial Perspective, 2nd edn., Lectern, Port Elizabeth.

Brønn, P.S. \& Vrioni, A.B., 2001, 'Corporate social responsibility and cause-related marketing: an overview', International Journal of Advertising 20(2), 207-222.

Carroll, A.B. \& Buchholtz, A.K., 2006, Business and Society: Ethics and Stakeholder Management, 6th edn., South Western, Ohio.

Chen, Y., 2010, 'The drivers of Green Brand Equity: Green Brand Image, Green Satisfaction, and Green Trust', Journal of Business Ethics 93(2), 307-319. http:// dx.doi.org/10.1007/s10551-009-0223-9

Claver, E., Lopez, M.D., Molina, J.F. \& Tari, J.J., 2007, 'Environmental management and firm performance: a case study', Journal of Environmental Management 84(4) 606-619. http://dx.doi.org/10.1016/j.jenvman.2006.09.012, PMid:17141938

Cohen, L., Manion, L. \& Morrison, K., 2007, Research methods in education, 6th edn., Routledge, Oxon.

Cooke, D., 2010, 'Building social capital through corporate social investment', Asia-Pacific Journal of Business Administration 2(1), 71-87. http://dx.doi. org/10.1108/17574321011028981

Crane, A. \& Matten, D., 2007, Business ethics, 2nd edn., Oxford University Press, New York.

Dockel, J.A. \& Ligthelm, A.A., 2005, 'Factors responsible for the growth of small businesses', viewed 10 March 2009, from http://www.sabinet.co.za/abstracts/ ecoman/ecoman_v8_n1_a6.html

Frederick, R.E., 2002, A companion to business ethics, Blackwell Publishing, Oxford. http://dx.doi.org/10.1111/b.9780631201304.2002.x, PMCid:125366

Ghillyer, A., 2008, Business ethics: A real world approach, McGraw-Hill, New York.

Griffin, R.W., 2008, Management, 9th edn., Houghton Mifflin, New York.

Hair, J.F., Babin, J.R., Money, A.H. \& Samouel, P., 2003, Essentials of business research methods, Wiley \& Sons, New Jersey.

Hair, J.F., Black, W.C., Babin, J.B., Anderson, R.E. \& Tatham, R.L., 2006, Multivariate data analysis, 6th edn., Pearson/Prentice Hall, Upper Saddle River, N.J.

Hair, J.F. Jr, Anderson, R.E., Tatham, R.L. \& Black, W.C., 1998, Multivariate data analysis with readings, 5th edn., Prentice Hall, New Jersey.

Hartman, L.P. \& DesJardins, J.R., 2011, Business ethics: decision making for personal integrity and social responsibility, 2nd edn., McGraw-Hill, New York.

Irwin, R., 2003, 'Corporate social investment and branding in the new South Africa', Journal of Brand Management 10(4), 303-311. http://dx.doi.org/10.1057/ palgrave.bm. 2540126
Jacobs, E., 2011, 'Executive brief: Differences in employee turnover across key industries', viewed 17 May 2012, from http://www.shrm.org/research/ benchmarks/documents/assessing\%20employee\%20turnover final.pdf

Javalgi, R.G., Traylor, M.B., Gross, A.C. \& Lampman, E., 2012, 'Awareness of sponsorship and corporate image: An empirical investigation', Journal of Advertising 23(4), $47-58$.

Jenkins, H., 2009, 'A "business opportunity" model of corporate social responsibility for small- and medium-sized enterprises'. Business Ethics: A European Review 18(1), 21-36. http://dx.doi.org/10.1111/j.1467-8608.2009.01546.x

Juntunen, M., Saraniemi, S., Halttu, M. \& Tähtinen, J., 2010, ,Corporate brand building in different stages of small business growth', Journal of Brand Management 18(2), 115-133. http://dx.doi.org/10.1057/bm.2010.34

Keller, K.L., 2008, Strategic brand management, 3rd edn., Pearson/Prentice Hall, New Jersey.

Kongolo, M., 2010, 'Job creation versus job shedding and the role of SMEs in economic development', African Journal of Business Management 4(11), 2288-2295.

Kumar, S. \& Tiwari, R., 2011, 'Corporate social responsibility: Insights into contemporary research', The IUP Journal of Corporate Governance 10(1), 22-45.

Lasher, W.R., 2008, Financial management: A practical approach, 5th edn., Thomson South-Western, Mason.

McWilliams, A., Siegel, D.S. \& Wright, P.M., 2006, 'Corporate social responsibility', Journal of Management Studies 43(1), 1-18. http://dx.doi.org/10.1111/j.1467 6486.2006.00580.x

Orlitzky, M., Schmidt, F. \& Rynes, S., 2003, ,Corporate social and financial performance: a meta-analysis', Organization Studies 24(3), 403-441. http:// dx.doi.org/10.1177/0170840603024003910

Santos, M., 2011, 'BSR in SMEs: strategies, practices, motivations and obstacles', Social Responsibility Journal 7(3), 490-508. http://dx.doi. org/10.1108/17471111111154581

Springer, K., 2010, Educational research: A contextual approach, John Wiley \& Sons, Inc., New Jersey.

SPSS Version 20.0., 2011, viewed 17 September 2013, from http://www-01.ibm.com/ software/analytics/spss

Statistica Version 10.0., 2010, viewed 19 September 2013, from http://www.statsoft. com

Swystun, J., 2007, The brand glossary, Palgrave Macmillan, New York.

Thorne, D., Ferrell, O.C. \& Ferrell, L., 2008, Business and society: A strategic approach to social responsibility, 3rd edn., Houghton Mifflin Company, Boston.

Uddin, M.B., Hassan, M.D. \& Tarique, K.M., 2008, 'Three dimensional aspects of corporate social responsibility', Daffodil International University Journal of Business and Economics 3(1), 199-212.

Visser, W., Matten, D., Pohl, M. \& Tolhurst, N., 2010, The A-Z of corporate socia responsibility, John Wiley \& Sons Ltd, West Sussex.

Vukasovic, T., 2009, 'Searching for competitive advantage with the aid of the BPI', Journal of Product and Brand Management 18(3), 165-176. http://dx.doi. org/10.1108/17471111111154581

Weber, M., 2008, 'The business case for corporate social responsibility: A companylevel measurement approach for CSR', European Management Journal 26(4), 247-261. http://dx.doi.org/10.1016/j.emj.2008.01.006

Werther Jr. W.B. \& Chandler, D., 2006, Strategic corporate social responsibility: Stakeholders in a global environment, Sage Publications, Inc., California.

Xepapadeas, A., 2008, 'Ecological economics', viewed 07 December 2012, from http://www.dictionaryofeconomics.com/article?id=pde2008_E000221\&q= ecological\%20economics\&topicid=\&result number $=1$

Zikmund, W.G., 2003, Business research methods, South Western, Ohio.

Zikmund, W.G., Babin, B.J., Carr, J.C. \& Griffin, M., 2010, Business research methods, 8th edn., South Western, Montreal. 